\title{
6. Stories my Grandmother Never Told Me: Recovering Entangled Family Histories Through Ego-Histoire ${ }^{1}$
}

\author{
Karen Hughes
}

In 1997, I accompanied the oldest Ngarrindjeri person, the distinguished storyteller, Aunty Hilda Wilson, then aged 86 and becoming a staunch friend, home to Country, to the Aboriginal community of Raukkan, the former Point McLeay Mission on the southern edge of Lake Alexandrina. Aunty Hilda was born there in 1911, a year that marked the legal separation of South Australian Aboriginal and settler peoples with the passing of the SA Aborigines Act 1911 . $^{2}$ As we stepped onto the shore of Lake Alexandrina, she led me to a clump of rushes in the sand, where her mother, Olive Varcoe (née Rankine), once sat and picked the fine but sturdy fibres with her sisters and Country-women, weaving the famous Ngarrindjeri baskets for sale and personal use. The women washed clothes here in a kerosene-tin over an open fire, gossiped and laughed, cared for little ones, and discussed important business. Aunty Hilda soon told me of sitting patiently alongside her great-grandmother, Ellen Sumner (1842-1925), at large ceremonial gatherings near this site during the 1910s and 1920s. From Ellen Sumner, renowned composer and singer, she also learnt Pata Winema, 'the old corroborree song'. Hilda claimed to discern the meaning of only one of its lyrics, lieuwen: to 'lay down', 'sleep' or 'rest'. Many believe this was adapted as a sorcery song against settlers for the destruction their intrusion brought (Bell 1998, p. 155).

Looking across the Lake in the blue haze of late afternoon, I suddenly recognised a familiar outline of pine trees, a miniature jetty, and the small rise of the town of Milang. Twenty kilometres north, Milang was the place of my grandmother's childhood, and of significant parts of mine. I had not been there for many years, after a decade and a half of living away, first in Sydney, then Italy and the United States. My maternal grandmother, Dorothy Johnson (née Pavy) (1909-2003), a third-generation descendant of French-English migrants from the 1850s, was born at Milang just 18 months before Hilda Wilson's birth on the mission. My

\footnotetext{
1 My grateful thanks to Glenda Ballantyne, Margaret Allen, Eleanor Hogan (and the anonymous peerreviewers) for insightful comments on this and earlier drafts.

2 Aboriginal people were subjected to similar 'Aborigines Acts' in other states over this period via which they were segregated and controlled.
} 
grandmother's birth narrowly preceded the passing of the Apartheid-style Aborigines Act SA 1911, which aimed to segregate the localities and lives of Aboriginal and settler peoples, in the wake of Australian Federation's 'whitening imperative'. ${ }^{3}$ Subsequently, it served to separate their histories.

\section{Up Close and Dangerous: De-familiarisation and the Making of a Settler-Colonial Historian}

That distinct moment at the end of 1997 began to radically shift my understanding of the interrelationship between history and self. Drawing on Pierre Nora's notion of ego-histoire, I explore the broader context of this moment and its impact on the way I have come to write and think about particular histories since. I also acknowledge the very significant methodological influence of feminist and Indigenous scholars (both community-based and in the academe) that predates and parallels Nora's work, in which the value of situatedness and standpoint is shown to be primary in producing more transparent, accountable scholarship (for example, Allen 2012; Rigney 2006; Harding 1991; Collins 1991; and Olsen 1978). I am long familiar with Nora's incisive work on memory. However, it is only with the publication of this volume that his analysis of ego-histoire has become widely available to English-speaking scholars through its first English-language translation. What registers as particularly useful to me as a non-Indigenous scholar doing history within the specific anxieties of the settler-colonial contact zone is Nora's identification of ego-histoire's capacity 'to defamiliarise a subject which we spontaneously inhabit' [emphasis mine]. ${ }^{4}$ Indeed, the shock of the familiar in my encounter with Aunty Hilda Wilson ultimately spurred my course as an historian and with it refigured my sense of belonging in a landscape I had previously assumed 'known'.

As a child in Adelaide, I frequently witnessed Aboriginal people in the outdoor spaces of the city, yet rarely found myself in situations of interpersonal contact. Although my parents had enjoyed somewhat limited contact with Aboriginal children in the classrooms and on the sporting fields of rural South Australia, by the time I came along we lived in Adelaide in a white, lower-middle-class suburb without Aboriginal friends. As Marcia Langton so famously and aptly said, 'most Australians do not know and relate to Aboriginal people. They relate to stories told by former colonists' (Langton 1993, p. 33).

\footnotetext{
3 See Grimshaw 2002, and Hughes 2012 on Federation's impact on Indigenous-settler relations and patterns of absence and presence in historiography.

4 Nora's 'L'Ego-Histoire est-elle Possible?' appears as an appendix to this volume.
} 
During my early twenties in Sydney, when writing about the city's music and arts scene for The Australian (for example, Hughes 2006), something compelled me to want to better understand Aboriginal cultures. Although difficult to pinpoint, it followed a spiritual experience on waking during a meditation retreat in Goulburn in 1981. When wondering how best to pursue this, an acquaintance encouraged me to contact Uncle Guboo Ted Thomas (1909-2002), the respected Yuin land rights activist and cultural educator at Wallaga Lake Aboriginal community on the New South Wales south coast (Goodall 1996, pp. 335-351). Generously responding to my telephone call, Ted Thomas, then in his mid-seventies, invited me to spend Easter of 1981 in the community with his family. He immersed me in a living history of palpable deep time, contrasting a half-day trek up sacred Gulaga Mountain, and the stories of ancient beings actively inhabiting its crevices, with documentary evidence archived in his personal filing cabinet of colonial and state atrocities. He interwove this with personal accounts of the resilience, enterprise and activism of Yuin people and culture. Later, Ted Thomas stayed with me on two short trips to Sydney for speaking invitations I had arranged. His main focus was on helping me see and understand differently, through a different historical paradigm and cultural lens drawn from Indigenous ways of speaking about the past, rather than merely consuming historical evidence. I am immensely fortunate to have begun my study in Aboriginal history with such an exceptional teacher. Ted Thomas's nephew, Burnum Burnum (1936-1997) (see Farnsworth 1997), also visited my house in Darlinghurst, sometimes with gifts of firewood and tea-tree leaves from the bush from which we brewed tea to fuel afternoons of conversation. He shared his concerns over cultural heritage and intellectual property protection, and the plans he was hatching to bring issues of Aboriginal sovereignty into the public arena, which culminated in his spectacular planting of the Aboriginal flag on English soil on Invasion Day, 1988 (historychannel.com.au 2014). Burnum Burnum, in particular, introduced me to the shocking, bitter history of the Stolen Generations, drawing on the sadness of his personal experience of being forcibly removed from his family in 1936 as a three-month-old baby, growing up in Bomaderry, and then the horrific Kinchella boys home (see Ramsland 2004). He gave me a copy of Peter Read's first treatise on the Stolen Generations (Read 1981). The now faded slim monograph has travelled with me across continents, a provocative reminder of why collaborative history is important, and a pointer of what still needs to be unearthed. The bookshop at Tranby Aboriginal Co-operative College became a further source of self-education and contact over this period, and in my journalism I began to publish interviews with Aboriginal musicians, film-workers and broadcasters. 
Returning to Adelaide in 1983 to work with the Aboriginal Jubilee 150 Committee $^{5}$ and architect Ian Hannaford on an Aboriginal Heritage Centre for South Australia,6 I was introduced to Ruth Heathcock (1901-1995), a remarkable non-Aboriginal nurse, a friend of former South Australian premier Don Dunstan. A decade older than my grandmother, Ruth was similarly raised around Lake Alexandrina. Yet, in contrast, Ruth had lived against the grain of her times, profoundly engaged with Aboriginal people and politics, mostly as a leprosy nurse in the Northern Territory (Hughes 2005). I wondered why Ruth's experience so differed to my grandmothers', and came to realise that such engagement was only really possible before the 1911 Act. Ruth had lived her first ten years before its passage, forming life-changing friendships with Ngarrindjeri children and families.

I directed a documentary about Ruth Heathcock's collaboration with Aboriginal women in the Northern Territory in 1984 (Hughes 1986), and through this I began a number of deep - now intergenerational - friendships with the family who adopted Ruth in the 1930s, and who later adopted me (Hughes 2013a). My classificatory-mother, the Ngukurr elder Rosalind Munur (1931-2005), significantly influenced my perspective and subjectivity over this decade, expanding the historical paradigm Ted Thomas had instilled during our trek up Gulaga Mountain. Over the years that followed, Rosalind patiently taught me ways of understanding and doing history from an expressly Indigenous epistemological and pedagogical base. She approached history holistically, seeing caring for stories as intrinsic to active custodianship of Country, ${ }^{7}$ and overall family and community well-being. It was her firm belief that histories resided in the bodies of people and in the land, and that historical knowledge is inalienable from this nexus. She showed me how knowledge travelled intergenerationally through genealogies, linked to specific Dreaming tracks and belonging to place. By adopting me as a daughter, Rosalind drew me into a correct relationship with that knowledge and began instructing me in an ethics of working and being by which it might be possible to begin to move toward a cross-cultural approach to history: as much socio-political and scholarly as deeply personal (Hughes 2013a).

5 The committee included Vi Deuschle (chair), Doreen Kartinyeri, Judy Lucas, Lewis O'Brien, and Val Power. 6 This later became Tandanya: National Aboriginal Cultural Institute, after Premier John Bannon refused to grant specific land on the River Torrens for the larger, purpose-built structure the committee had requested. 7 Throughout, I use the Aboriginal-English term 'Country' (as distinct from the standard AustralianEnglish meaning), which encompasses home, clan estate, and the powerful complex of spiritual, animate and inanimate forces which bind people and place. 


\section{Elemental Forces and Purposeful Ghosts}

Pointing to Freud's concept of 'the uncanny' as a trope fundamental to settler experience, Ken Gelder and Jane Jacobs contend that an 'uncanny' experience occurs when 'one's home - one's place - is rendered somehow and in some sense unfamiliar; one has the experience, in other words, of being in place and "out of place" simultaneously. This happens precisely at the moment when one is made aware that one has unfinished business with the past, at the moment when the past returns as an "elemental" force [emphasis mine] ... to haunt the present day' (Gelder \& Jacobs 1996, p. 111).

When I saw my grandmother's birthplace and the site of my childhood from the 'othered' shore, history for me became an elemental force. It was at that point that I began to fully perceive my family history and Ngarrindjeri history recalibrated in the same geo-social space-intersubjective and entangled.

Before, Lake Alexandrina had floated in my earliest memories as a mythic childhood place of creamy limestone cottages, hypnotic silvery water and elderly relatives - a site of great but un-investigated power, in which emanations of a deeper ancestral past resided, yet without clear articulation. I now began to question what exactly those traces were, and how they were constituted. What were the implications of my family's past in the Lower Murray lakes for Ngarrindjeri? My questions acted as 'purposeful ghosts', urging me to re-search this past as a way of explaining a now defamiliarised present.

The cultural theorist, Gail Jones, described the significance of an 'imagined real' in navigating through subterranean histories, suggesting that 'any child, who imagines her own history, re-dreams it, enters impossible perspectives ... performs the transitive and transferential, recognises in an almost intuitive way that her nation has various and diverse "situated knowledges" within it" (Jones 2006, p. 14).

Perhaps because my mother died when I was in adolescence, I retain heightened memories of her stories. Many of these belonged to Milang and the Lake, centering on vivid recollections of my mother's great-grandmother Louisa Coad (née Mott) (1851-1946), a lithe, strict woman in Victorian black, who stitched delicate 'log-cabin' patchworks and chased my mother around the veranda with a broomstick for eating almonds she was supposed to be shelling. Louisa's personal qualities of matrilineal authority, independence and creativity were discussed widely among our family. These stories mostly emphasised how Louisa, as an old woman, came back to the flat watery landscape of Milang from an even more mythic place, 'Ned Kelly country' in Victoria, to help out after her daughter (my great-grandmother) was widowed in 1935. 


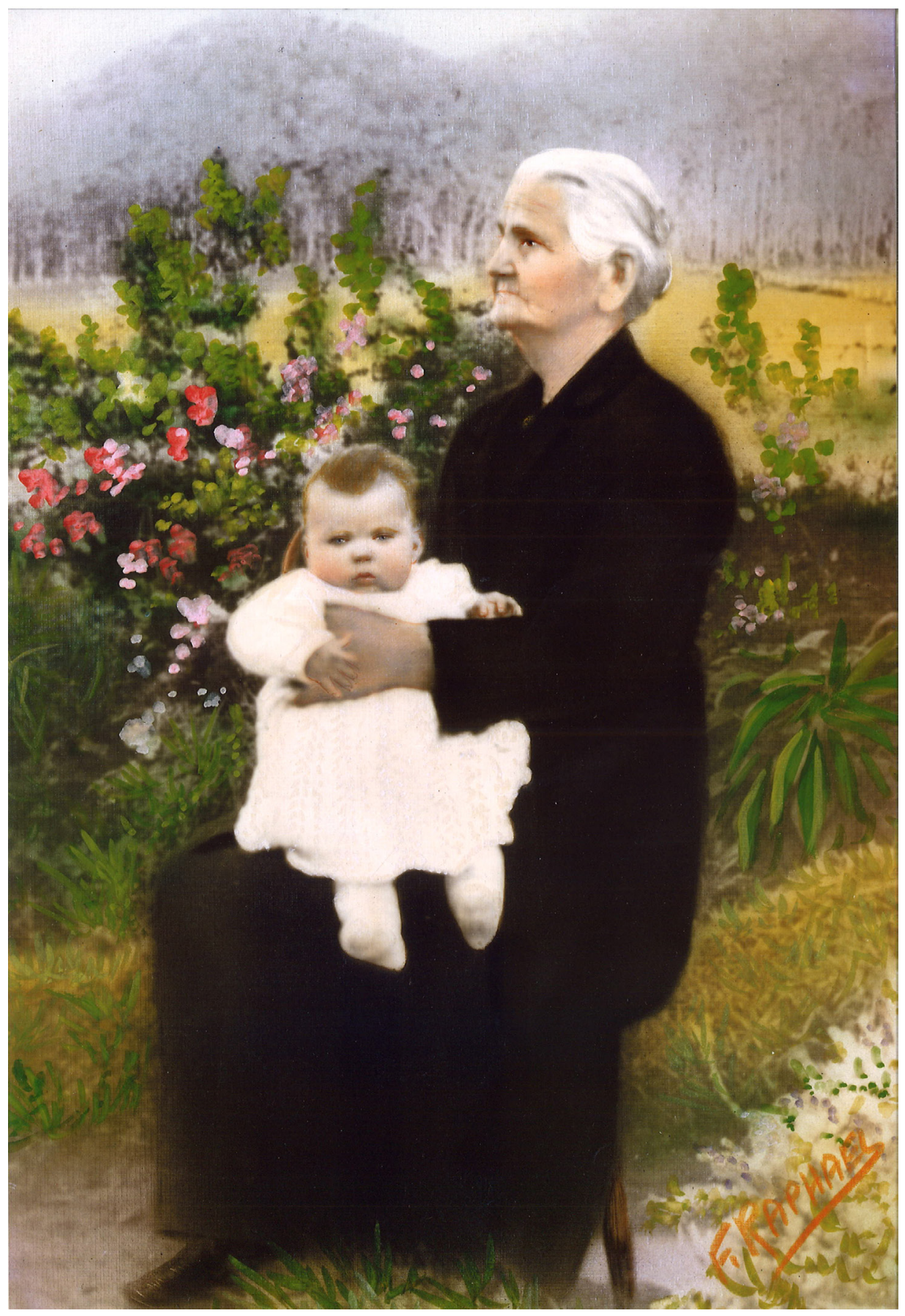

Louisa Coad at Tawonga, Victoria, c. 1940, painted photograph.

Source: Courtesy of Mrs Amy Ladson, collection of the author. 
Louisa Karpany (on right), c. 1910.

Source: Courtesy of Ellen Trevorrow and the South Australian Museum. 
As a child of seven, I would float on the Lake's brackish waters on hot summer afternoons and extend these sparse memory-fragments to imagine that Louisa (before her white hair and widows' gowns) had been Ned Kelly's lover. I remained convinced that, in time, a secret letter would emerge, hidden in an attic, verifying my great-great grandmother's agency in history. She was 'the woman behind the man', the only place she could have occupied in the Australia of that time, as well as the Australia of my 1960s imagination.

My creative dream-space, with its impossible leaps of agency and place, was indelibly linked to 'remembering' the Lake, and indeed my maternal lineage, through an improbable white male resistance history, embodied in the mythic figure of Kelly. Yet it was this listening for deeper layers of meaning, as Gail Jones suggests, that inspired my search for 'situated knowledges' and continuity of story as I grew. It also revealed much of my childish positioning of self in a suburban nuclear family during Australia's deeply assimilationist 1950s and early 1960s, in which powerful women were marginalised and Aboriginal peoples barely visible (Stanner 2011, pp. 182-191), Kelly's dislocated mask, superimposed across the Lake's surface, usurped the space where localised stories of strong, skilled women and enduring Aboriginal presence continued. Later, I was told of another Louisa, the Ngarrindjeri woman 'Queen' Louisa Karpany (née Kontinyeri) (c.1821-1921), who also dressed in black Victorian gowns, and whose presence in the landscape is still tangible. Eventually, I would come to work closely with some of her descendants (see Hughes \& Trevorrow 2014).

\section{A Place of Sorcery}

Gazing across to my grandmother's birthplace while standing beside the oldest living Ngarrindjeri woman from Point McLeay, I wondered at the possibilities for interconnectedness in these women's lives, which had paralleled each other over most of the twentieth century. Overwhelmingly I grasped the sense of missed encounters and lost possibilities. As children on opposite sides of Lake Alexandrina, and with the far wider gulf imposed by the Aborigines Act SA 1911, each was quite differently caught in the vortex of its ongoing consequences. In listening to the stories of Aunty Hilda Wilson and the other elders she introduced me to in the decade that followed, I became aware of how these consequences continued to unfold for the subsequent generations of their families, as for Australian society at large. The name 'Milang' itself, I discovered, was appropriated from the displaced Ngarrindjeri name, Milangk: "place of sorcery'. Now Milang and Lake Alexandrina became a site of defamiliarisation and transformation, contributing to a revised identity and more complex sense of belonging and historical understanding. 
I hoped a visit to my grandmother Dorothy might shed further light on our interwoven, intersecting pasts. In 1997, Dorothy was living just north of Milang in Strathalbyn. She possessed a lucid memory, although rarely one to indulge in the 'country of the past' ${ }^{8}$ Excited by my discoveries, I bombarded her with a torrent of questions, beginning with:

'Nanna, do you remember Aboriginal people living around Milang when you were a child?'

'There weren't any', she replied.

As I told her about accompanying Aunty Hilda Wilson to the former Point McLeay Mission she became animated, interrupting excitedly:

'I've been to Point McLeay'.

'What for?'

'The football!' she exclaimed.

On a number of occasions, my grandmother revealed, she had crossed Lake Alexandrina as a child to watch her father, her brothers and cousins in the Milang football team. Staggeringly, I was to discover they were competing against Hilda Wilson's brothers and cousins in the Point McLeay team, which was captained by Aunty Hilda's father, Wilfred Varcoe, in a game umpired by her grandfather, William Rankine (personal communication with Hilda Wilson, 1998). Dorothy described these Milang vs Point McLeay matches as 'wild', suggestive of the boundary-crossing inherent in the engagement of the occasion. Remarkably, I realised, rather than actively remembering the spectacle of the oval and its players, the act of crossing the Lake by wood-powered steamer boat, and the pleasure of these culturally transgressive intercommunity events, my grandmother had internalised a construction of settler-colonialism's grand narrative that there 'weren't any' Aboriginal people around Milang. So strong was this fiction, that it was only when I regaled her with Aunty Hilda's stories that she began to relate vivid memories of football matches between the two communities, often followed by picnics and dances - at a time when she said 'football was all there was' — with an Aboriginal presence (Hughes 2012, pp. 270-273).

Browsing the local history book, Alexandrina's Shore, lent by my mother's sister, I found a photograph of the Milang football team taken in 1897, a century earlier. It portrays Dorothy's father, my great-grandfather Tom Pavy, and Aunty Hilda's grandfather William Rankine, together in the frame. The photo

8 I refer to David Lowenthal's (and L P Hartley's) celebrated phrase, 'the past is another country' (Lowenthal 1985). 
also reveals a third of the players in the 1897 Milang team to be Ngarrindjeri, although the Ngarrindjeri players are not named in the caption. Another prominent Ngarrindjeri elder, Ben Rigney, (who ran the mission butcher shop in conjunction with Milang's butcher, Ted Burgess, my grandmother's cousinin-law), is also in the team. Elsewhere in the book, relegated to a chapter entitled 'Aborigines, Explorers and Wild-Life', was a photograph of Hilda's grandfather, William Rankine, with his infant daughter, Hilda's mother, Olive, on his lap. Later, exploring these photographs at my aunt's house, Aunty Hilda and I were able to put some of our overlapping stories together. These compelling images from more than a century before provided a valuable window into a more culturally diverse and interconnected world, hinting at biculturalism, negotiation and coexistence largely overwritten in later remembrance and localised constructions of settler identity (Hughes 2012, p. 273).

My grandmother also summoned a very early memory of Ngarrindjeri ngowanthi or wurlies on the Lake edge, where the Milang caravan park now sits, stretching across the foreshore to Lake Plains where her family had farmed. Late nineteenth-century drawings, too, record these Ngarrindjeri homes, but little is written of the everyday relations between the Ngarrindgeri families, estimated to comprise around 200 people (Burgess c.1980), and the recently arrived European townspeople, the kringkari, who 'shared' this space from the late 1840s until at least several years after the Act. In my grandmother's memory, the wurlies 'disappeared' by the late 1910s, but Aunty Hilda was able to provide names, faces and voices to at least one of the families in the Milang wurlies: that of her great-grandparents, Ellen Sumner and John Rankine, and their five children, including Aunty Hilda's grandfather, William Rankine. Theirs is a rich family story that stretches forward to descendants who now flourish in contemporary Australian society and public life, such as the former AFL football player Michael O'Loughlin and 2014 Australian of the Year, Adam Goodes.

Questions raised by the patterns of absence and presence in settler memory drove my doctoral research at Flinders University, exploring the intersection of Ngarrindjeri and settler history (Hughes 2009). This held broader implications for the way racialised, gendered and classed histories in Australia are locally and intimately constituted (Hughes 2012, 2013). Retracing my maternal genealogy, I sifted through signs that remained in letters, photos, household objects, in the landscape itself, and, most fruitfully, in conversations with those in the present. Surprisingly, it was mostly Ngarrindjeri people's recollections that enabled me to fill the gaps in my family's history.

Reputedly well-regarded across the cultural divide (personal communication with Madge Williams, 2000), my maternal grandfather, Hughie Keough, was a travelling picture-showman who brought the first silent films to the Lower 
Murray towns, including the Point McLeay Mission, from the 1910s to the 1930s. Unfortunately, I was never able to hear his stories, for he died just months before I was born. Moreover, Dorothy, my grandmother, burnt most of his belongings (including films that he had made), but I treasure his small box brownie camera handed on from my mother. Ngarrindjeri loved the new medium of cinema so much that when they first travelled the two kilometres from Point McLeay to Narrung to see the movies, they filled and spilled out of the hall, soon building their own hall for the movies beside the mission church (personal communication with Leta Padman, 2009). At this time, the knowledgeable and respected Ngarrindjeri elder, Albert Karloan, in 1919 had an enterprising plan to make his own films and travel with his son Clem, showing movies, telling stories. This likely would have been the first Indigenous filmmaking venture in the world, but Albert Karloan was refused a loan to buy a cinematograph by the chief 'protector' of Aborigines, R. D. South, despite a letter of resounding support from Point McLeay's superintendent (Mattingly 1988, p. 125). It was quite possibly my grandfather who encouraged this venture and offered to procure a cinematograph. Whenever my grandfather pulled up to the mission hall, a small boy, Matthew Kartinyeri, waited to greet him and help carry his bag up the stairs to set up the reels in the projectionist's aerie. Matthew was never known by his birth-name, only by his nickname, Pictureman, which he continued to be called throughout his life, and which is now on his headstone (personal communication with Noreen Kartinyeri \& Verna Koolmatrie, 2011). Although my aunt had earlier told me about her father taking the movies to Point McLeay, these were not stories told by my grandmother, but by Ngarrindjeri living today at Raukkan, and from Pictureman's daughter, Aunty Noreen Kartinyeri.

Other connections emerged that had been edited from my family's active remembering, including a marriage between my grandmother's second-cousin, Irene Coad, and the Ngarrindjeri man Walter McHughes early in the twentieth century. I was delighted that some of their 13 children were living. Their 80-year-old son, John McHughes, embraced me as 'cuz', describing the racism his mother endured-including from some of her sisters - for marrying black. I have to still meet John McHughes's sister, Betty Lorraine, who bears the same Christian names as my mother, Betty Loraine Hughes, living in parallel.

Another woman, Christina Black, further back in time, intrigued me. A greataunt to my grandfather, Hughie Keough, she lived at Lake Plains in the 1840s, close to where Milang was later established. Thought to be an Irish-born servant, and known as 'generous hearted Christie', Christina broke ranks and openly sympathised with Ngarrindjeri dispossession, 'freely sharing her provisions with them'. 'Poor people', she is recorded to have said, 'we have taken their land' (Donald and Christina McLean Genealogical Council 1995, p. 203). 
The reason for Christina's husband's explicit disinheritance from the large estate, amassed by his Scottish-born father Donald McLean, in the nascent years of the colony, however, is not stated, but perhaps implied by her renegade actions. Living against the currents of her times, her voice was a rarity. Intriguingly too, a Ngarrindjeri child born in the 1850s shares her name (Kartinyeri 2007, p. 80).

My father, Dean Hughes, was born elsewhere, in the dry mallee country inland from the Murray river-town of Loxton. His family walked off the land during the Great Depression drought in 1939. They leased a dairy-farm on Hindmarsh Island, in the Murray Mouth - an island with special significance for Ngarrindjeri women, at the centre of a distressing legal case in the 1990s (see Bell 1998). My father played football for the mainland town, Goolwa, alongside Ngarrindjeri sporting legend Herbert Rigney and, during the Second World War, shared a military hospital-ward and combat stories with Tim Hughes, the highly decorated Kaurna/Narrunga soldier. Yet his primary-school history book from a one-room school house in Wanbi in the 1930s (which I coveted as a child) makes only a single mention of Aboriginal peoples, as being 'extinct', while Captain Cook beams majestically from the cover (Granger n.d., p. 31). Moreover, his father, Alfred Hughes, was delivered in a tent under several inches of rising floodwaters on the Teetupla goldfields at Waukaringa on New Year's Day, 1888, by a skillful Aboriginal midwife, probably an Adnyamathanha woman. Such textual and material fragments allude to richer intersubjectivities and the potentiality of possible encounters, in 'unpicking of imperial histories' (Hall 1996, p. 76), but also to the missed encounters and lost social relationships found in cross-cultural reweaving.

\section{'Learning to fall in love with your country'}

In the decade that followed my 'epiphany' by the Lake at Raukkan, Aunty Hilda Wilson periodically fuelled my sense to know more, instructing me in histories, genealogies, stories and songs of her Country, and ancestors, which shaped my subsequent work. As with Rosalind Munur, history, Country and kin were inseparable. Stories were revealed where events had occurred as we travelled to visit friends and relations and to places of significance along the Coorong and in Adelaide homes. Slowly, too, I became part of a wider sense of kin as our relationship became family-like. Aunty Hilda passed away in 2007 at the age of 96, ten years after that first trip to Raukkan with her. She remained in good health until her death, singing songs and telling stories to her family and the hospital-nurses even in her final hours. For her, too, history had remained an elemental force. 
Moreover, she had never allowed colonial intrusion to erode her sense of cultural sovereignty and Aboriginal identity (Hughes 2013b). Her granddaughter, Aunty Ellen Trevorrow, the renowned Ngarrindjeri weaver and cultural educator, and I now collaborate on a range of projects, as my learning continues (Hughes \& Trevorrow 2014). But more than this, we have become an integral part of each other's family life, sharing the joys and the crises life throws before us.

Deploying ego-histoire as an historical method enabled a finely granulated appreciation of settler-colonial histories as a complex interweave of localised, intimate and intersubjective family histories (Haskins 1999). This encouraged me to pursue a microhistorical approach and a cross-cultural sensibility in my subsequent work, drawing in particular on Minoru Hokari's call for the need to cross-culturalise the discipline of history itself (Hokari 2011). The contact zone is co-creative and without closure, reaching across time, generations and space. Things can be otherwise. My sense of place is entirely different than before, and it is no longer possible to tell one story without the other, or to write histories of here or elsewhere to which I am disconnected. Bruce Pascoe calls this coming into knowledge of the settler-colonial atrocities, the unexpected ruptures of kindness, the injustices, the misunderstandings, the whole wham-bam thing, as 'learning to fall in love with your country' (Pascoe 2007).

\section{Epilogue: 'Time-travelling'}

Not long ago, after moving to Melbourne, I met one of Louisa Coad's few surviving grandchildren, Amy Ladson, a younger cousin of my grandmother, Dorothy. Amy had cared for Louisa in her final years, when she could barely walk, during the 1940s, in the small Alpine community of Tawonga in northeastern Victoria. One long weekend, I drove there with Aunty Amy to meet others descended from Louisa. As night fell, family members assembled at the home of Louisa's great-grandson, Harold Coad. Many brought photographs inherited from Louisa's personal collection. These were shared around the dining table along with stories of the various photographic subjects and their connections to each of us. I gasped aloud with excitement as a large image caught my attention. Cardboard-backed and fraying at the edges, taken by a professional photographer in the 1890s, it featured a young non-Aboriginal man sharing a picnic outdoors with an Aboriginal man of similar age on a rural property. They sit together comfortably; their pose is unusual, hinting at a social relationship as much as a working one. Turning it over, I found written the names of its actors, likely written by Louisa's hand: Bill Bartholomew (Louisa's older brother's son) and Bob Pinkey, a name I instantly recognised as being Ngarrindjeri/Boandik from the Bordertown region in south-eastern South Australia. I felt as if I had been waiting for this photo for most of my life. 


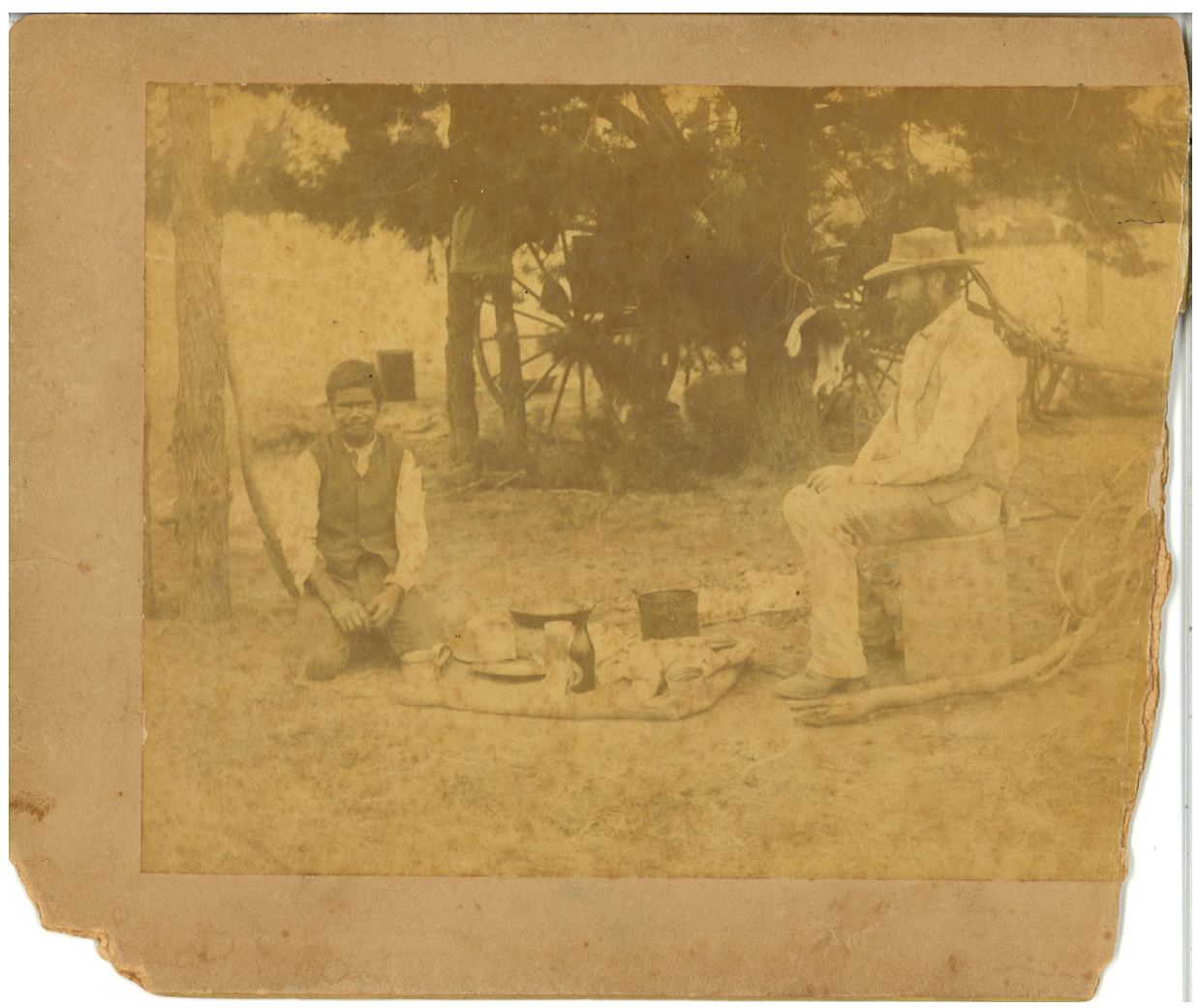

Bob Pinkey and Bill Bartholomew, Bordertown, South Australia, c. 1890.

Source: Photographer unknown, courtesy of Mrs Hazel Coad.

\section{References}

Allen, M 2012, 'Impeccable Timing: A personal reflection', Australian Feminist Studies, vol. 27, no. 73.

Bell, D 1998, Ngarrindjeri Wurruwarrin, Spinifex, Melbourne.

Burgess, E c.1980, taped interview, Milang and District Historical Society.

Collins, P H 1991, 'Learning from the Outsider Within: The sociological significance of black feminist thought', in J Hartman \& E Messer-Davidow (eds), Gendering Knowledge, University of Tennessee Press, Knoxville.

Donald and Christina McLean Genealogical Council 1995, History of Donald and Christina McLean and their Descendants: First wheat crop growers in South Australia, 1838, Milang, South Australia. 
Farnsworth, C 1997, 'Burnum Burnum, 61, Fighter For Australia's Aborigines', The New York Times, August 20, 1997. Available at: http://www.nytimes. com/1997/08/20/world/burnum-burnum-61-fighter-for-australia-saborigines.html.

Gelder, K \& J M Jacobs 1996, 'The Postcolonial Ghost Story,' Journal of the Association for the Study of Australian Literature, special issue, 'Current Tensions: Proceedings of the 18th Annual conference 6-11 July 1996', pp. 110-120.

Goodall, H 1996, From Invasion to Embassy: Land in Aboriginal politics in NSW from 1770 to 1972, Allen \& Unwin, Sydney.

Granger, W (ed) n.d., Australia's Story Told in Pictures, John Sands, Sydney.

Grimshaw, P 2002, 'Federation as a Turning Point in Australian History', Australian Historical Studies, vol. 33, no. 118, pp. 25-41.

Hall, C 1996, 'Histories, Empires and the Post-Colonial Moment', in I Chambers \& L Curtis (eds), The Postcolonial Question: Common skies, divided horizons, Routledge, London.

Harding, S 1991, Whose Science? Whose Knowledge?: Thinking from women's lives, Cornell University Press, New York.

Haskins, V 1999, ‘Family Histories, Personal Narratives and Race Relations History in Australia', Canberra Historical Journal, vol. 45, pp. 25-29.

historychannel.com.au 2014, 'The Burnum Burnum Declaration of 26 January 1988'. Available at: http://thepeoplespeak.thehistorychannel.com.au/ speeches/burnum-burnum/.

Hokari, M 2011, Gurindji Journey: A Japanese historian in the outback, UNSW Press, Sydney.

Hughes, K 2013, 'I'd Grown up as a Child Amongst Natives: Ruth Heathcock', Outskirts: Feminisms along the Edge, vol. 28. Available at: http://www. outskirts.arts.uwa.edu.au/volumes/volume-28/karen-hughes.

Hughes, K 2013a, ‘Becoming Rosalind's Daughter: Reflections on intercultural kinship and embodied histories,' Journal of the European Association for the Study of Australasia, vol. 4, no. 1, pp. 76-91.

Hughes, K 2013b, 'Resilience, Agency and Resistance in the Storytelling Practice of Aunty Hilda Wilson (1911-2007), Ngarrindjeri Aboriginal Elder', MediaCulture Journal, vol. 16, no. 5. Available at: http://journal.media-culture.org. $\mathrm{au} / \mathrm{index} . \mathrm{php} / \mathrm{mcjournal} / \mathrm{article} / \mathrm{view}$ Article/714. 
Ngapartji Ngapartji, In Turn, In Turn: Ego-histoire, Europe and Indigenous Australia

Hughes, K 2012, 'Microhistories and Things that Matter: Opening spaces of possibility', Australian Feminist Studies, vol. 27, no. 73, pp. 269-278.

Hughes, K 2010, 'Fluid Waters: Cultural exchange in the land of the Ngarrindjeri, a poetics and a politics', Le Simplegadi, vol. 8, no. 8, pp. 24-35.

Hughes, K 2009, 'My Grandmother on the Other Side of the Lake', unpublished PhD thesis, Department of Australian Studies and Department of History, Flinders University.

Hughes, K 2006, 'Bob Dylan: The Sydney interview', in J Cott (ed.), Bob Dylan: The essential interviews, Hyperion, New York, pp. 237-251.

Hughes, K 2005, “'Same Bodies, Different Skin": Ruth Heathcock', in A Cole et al. (eds), Uncommon Ground: White women in Aboriginal history, Aboriginal Studies Press, Canberra, pp. 83-106.

Hughes, K 1986, Pitjiri: The snake that will not sink, (DVD re-release 2008), Ronin Films, Canberra.

Hughes, K and E Trevorrow 2014, “It's that Reflection": Ngarrindjeri photography as recuperative practice', in J Lydon \& S Braithwaite (eds), Calling the Shots: Aboriginal photographies, Aboriginal Studies Press, Canberra, pp. 175-204.

Jones, G 2006, 'A Dreaming, a Sauntering: Re-imagining critical paradigms', Journal of the Association for the Study of Australian Literature, vol. 5, pp 11-24.

Kartinyeri, D 2007, Ngarrindjeri Nation, Wakefield Press, Adelaide.

Langton, M 1983, 'Well, I Heard it on the Radio and I Saw it on the Television: An essay for the Australian Film Commission on the politics and aesthetics of filmmaking by and about Aboriginal people and things', Australian Film Commission, Sydney.

Lowenthal, D 1985, The Past is a Foreign Country, Cambridge University Press, Cambridge.

Mattingly, C, et al. 1988, Survival in Our Own Land, Wakefield Press, Adelaide.

McKenna, M 2002, Looking for Blackfellas' Point: An Australian history of place, UNSW Press, Sydney.

Olsen, T 1978, Silences, Delacorte Press, New York.

Pascoe, B 2007, Convincing Ground: Learning to fall in love with your country, Aboriginal Studies Press, Canberra. 
Ramsland, J 2004, 'Bringing up Harry Penrith: Injustice and becoming Burnum Burnum - the formative years of a child of the Stolen Generation', Education Research and Perspectives, vol. 31, no. 2, pp. 94-106.

Read, P 1981, 'The Stolen Generations: The removal of Aboriginal children in New South Wales, 1883 to 1969', New South Wales Ministry of Aboriginal Affairs, Sydney.

Rigney, L 2006, 'Indigenist Research and Aboriginal Australia', in J Kunnie \& N Goduka (eds), Indigenous Peoples' Wisdom And Power: Affirming our knowledge through narratives, Ashgate, Bodmin, pp. 32-50.

Stanner, W E H 2011, 'The Great Australian Silence', in The Dreaming and Other Essays, Black Inc, Melbourne, pp. 182-191. 
This text taken from Ngapartji Ngpartji: In turn in turn:

Ego-histoire, Europe and Indigenous Australia

Edited by Vanessa Castejon, Anna Cole, Oliver Haag and Karen Hughes,

published 2014 by ANU Press, The Australian National University, Canberra, Australia. 